\title{
RET Gene
}

National Cancer Institute

\section{Source}

National Cancer Institute. RET Gene. NCI Thesaurus. Code C18257.

This gene plays an essential role in neural crest development, cellular growth and

differentiation. Mutations in the gene are associated with a variety of neoplasias and carcinomas. 